\title{
Pengaruh Cara dan Waktu Penyimpanan terhadap Susut Bobot, Kadar Glukosa dan Kadar Karotenoid Umbi Kentang Konsumsi (Solanum tuberosum L. Var Granola)
}

\section{The Methods and Time Storage Effect on Weight Loss, Glucose Level, and Carotenoid Level of Potato}

\author{
Edi Purnomo ${ }^{1}$, Sri Widodo Agung Suedy ${ }^{2}$, Sri Haryanti ${ }^{2}$ \\ ${ }^{1)}$ Program Studi Biologi, Departemen Biologi, Fakultas Sains dan Matematika, Universitas Diponegoro \\ ${ }^{2)}$ Departemen Biologi, Fakultas Sains dan Matematika, Universitas Diponegoro \\ Jl. Prof. Soedarto, SH, Tembalang, Semarang \\ *Email: agung.suedy@gmail.com
}

Diterima 27 September 2015 / Disetujui 19 Juni 2017

\begin{abstract}
ABSTRAK
Penyimpanan produk pertanian merupakan hal yang penting dilakukan dalam penanganan pasca panen. Kentang merupakan produk hortikultura yang mudah rusak, sehingga dibutuhkan penanganan yang baik untuk mempertahankan kualitasnya sebagai salah satu bahan pangan fungsional. Penelitian ini bertujuan untuk mengetahui pengaruh cara dan waktu penyimpanan terhadap kualitas pada kentang konsumsi. Rancangan penelitian yang digunakan adalah Rancangan Acak Lengkap (RAL) faktorial dengan 2 faktor. Faktor pertama yaitu cara penyimpanan; disimpan pada wadah terbuka (K1) dan disimpan pada wadah berpenutup (K2). Faktor kedua adalah waktu penyimpanan dengan (T1); 2 minggu, (T2); 4 minggu, (T3); 6 minggu, (T4); 8 minggu, (T5); 10 minggu. Penelitian terdiri dari 10 perlakuan dengan 3 ulangan. Parameter penelitian terdiri: susut bobot kadar glukosa dan kadar karotenoid. Analisis data yang digunakan adalah Analysis of Variance (ANOVA) yang dilanjutkan dengan uji lanjut Duncan Multiple Range Test (DMRT) pada taraf signifikasi 95\%. Hasil penelitian menunjukkan bahwa cara penyimpanan di wadah terbuka (K1) cenderung meningkatkan angka susut bobot dibandingkan cara penyimpanan pada wadah berpenutup (K2), sedangkan waktu penyimpanan $(\mathrm{T})$ cenderung menurunkan kadar glukosa dan kadar karotenoid umbi kentang konsumsi. Interaksi antara cara dan waktu penyimpanan tidak berpengaruh nyata terhadap susut bobot, kadar glukosa dan kadar karotenoid ( $>0,05)$. Penyimpanan umbi kentang konsumsi sebaiknya dijauhkan dari adanya kehadiran cahaya dengan masa simpan kurang dari 4 minggu.
\end{abstract}

Kata kunci: cara penyimpanan, waktu penyimpanan, Solanum tuberosum L., kualitas

\begin{abstract}
Agriculture product storage is an important thing that must be done in post harvest handling. Potato is one of the easily broken product, so that a good handling is needed to mantain quality as one of functional food. This study aims to know influence of the method and time of storage for the quality of potato consumption. This research uses Completely Randomize Design for two factors. First factor was method storage: in open container (K1) and in close container (K2). Second factor was time storage with (T1); 2 weeks, (T2); 4 weeks, (T3); 6 weeks, (T4); 8 weeks, (T5); 10 weeks. This research uses 10 treatments and 3 replications. The parameter includes weight loss, glucose and carotenoid levels. The analysis was used ANOVA, followed by Duncan's test at the 95\% significance level. The results showed that storage method in open container (K1) tends increase weight loss and storage method in close container (K2) decrease, whereas storage time tend decrease glucose and carotenoid levels. The combination method and time of storage no effect in weight loss, glucose and carotenoid levels ( $p>0,05)$. Storage of potato consumption had better kept at a distance from light presence less 4 weeks.
\end{abstract}

Keywords: storage method, storage time, Solanum tuberosum L., quality 


\section{PENDAHULUAN}

Kentang (Solanum tuberosum L.) merupakan salah satu komoditas hortikultura dari kelompok tanaman sayuran umbi yang sangat potensial sebagai sumber karbohidrat. Kentang memiliki potensi dan prospek yang baik untuk mendukung program diversifikasi dalam rangka mewujudkan ketahanan pangan berkelanjutan (The International Potato Center, 2008). Kentang merupakan salah satu bahan makanan yang mengandung jenis karbohidrat kompleks (Jufri, 2011).

Kandungan karbohidrat pada kentang mencapai sekitar $18 \%$, protein $2.4 \%$ dan lemak $0.1 \%$. Total energi yang diperoleh dari 100 gram kentang adalah sekitar $80 \mathrm{kkal}$ (Astawan, 2004). Warna kuning pada kentang disebabkan oleh adanya kandungan $\beta$-karoten. Lidya (2010) menyatakan bahwa $\beta$-karoten adalah salah satu zat antioksidan yang terdapat pada buah-buahan misalnya buah peach dan umbi sepeti kentang dan wortel. Karotenoid umumnya terletak pada organ penimbun. Contohnya yaitu kentang (Morris et al., 2004), labu (Pandey et al., 2003).

Kentang umumnya dimanfaatkan sebagai makanan pokok. Kentang juga seringkali dimanfaatkan sebagai bahan makanan cemilan baik yang diolah secara tradisional maupun yang sudah modern dengan menggunakan alat pengolah. Rismawati (2009) menambahkan bahwa kentang dapat dikreasikan menjadi perkedel, kroket, kripik kentang, krupuk kentang, kentang goreng, dsb. Berbagai jenis produk olahan kentang ini membutuhkan pasokan kentang yang berkualitas sebagai bahan baku, baik dalam segi fisik maupun kandungan nutrisinya.

Umbi kentang merupakan salah satu jenis bahan baku pangan yang sangat digemari oleh konsumen sehingga ketersediaannya selalu diupayakan demi mendukung permintaan pasar yang cukup tinggi. Salah satu upaya yang umum dilakukan yaitu dengan perlakuan penyimpanan. Selama penyimpanan proses metabolisme terus berjalan (Kusdibyo, 2004). Salah satu proses metabolisme yang terjadi pada umbi kentang selama penyimpanan yaitu proses respirasi.
Campbell et al. (2002) menjelaskan respirasi adalah proses penguraian cadangan bahan makanan tumbuhan yang menghasilkan energi. Laju respirasi produk dipengaruhi oleh beberapa faktor, salah satunya yaitu faktor eksternal. Wardkan (2010) menjelaskan faktor eksternal yang berpengaruh dalam laju respirasi meliputi suhu, etilen, $\mathrm{O}_{2}$ dan gas $\mathrm{CO}_{2}$.

Kehadiran $\mathrm{O}_{2}$ selama penyimpanan sangat harus diperhatikan, hal ini dikarenakan dapat mempengaruhi laju respirasi. Cara penyimpanan di wadah terbuka akan lebih lama berinteraksi dengan udara dibandingkan dengan cara penyimpanan di wadah berpenutup. Semakin tinggi laju respirasi pada produk penyimpanan maka dapat menurunkan kualitas umbi kentang seiring dengan lamanya penyimpanan. Perlakuan cara dan waktu penyimpanan merupakan latar belakang dilakukannya penelitian ini dengan tujuan untuk mengetahui seberapa besar pengaruhnya terhadap penurunan kualitas umbi kentang selama penyimpanan.

\section{METODE PENELITIAN}

\section{Tempat dan Waktu Penelitian}

Laboratorium Biologi Struktur dan Fungsi Tumbuhan, Jurusan Biologi, Fakultas Sains dan Matematika, Universitas Diponegoro.Waktu penelitian dilakukan dari bulan Maret-Mei 2013

\section{Bahan dan Alat}

Bahan-bahan yang digunakan adalah umbi kentang, akuades, aseton $80 \%$, alkohol $80 \%$, DNS (Dinitro Salisilic Acid), $\mathrm{NaOH}$, kertas $\mathrm{pH}$ dan alumunium foil. Alat-alat yang digunakan pada penelitian ini yaitu spektrofotometer digital Shimadzu 1240, kamera digital, cuvet, mortar dan pestel, tabung reaksi, kertas saring, timbangan digital, lux meter, magnettic stirer, penangas, termohigrometer, cutter, penggaris, pipet tetes, dan kertas label.

\section{Pengambilan sampel dan penyortiran}

Umbi kentang yang digunakan sebagai sampel adalah Solanum tuberosum L. Var Granola yang berasal dari Desa Parikesit, Kecamatan Kejajar, Kabupaten Wonosobo dengan umur panen 
100 hari. Penyortiran dilakukan untuk mendapatkan ukuran yang seragam (diameter $40-45 \mathrm{~mm}$ ). Umbi yang dipilih tidak mengalami cacat fisik seperti kulit umbi yang terkelupas.

\section{Pembuatan wadah dan peletakan penyimpanan}

Wadah penyimpanan dibuat dari kertas kardus yang dibentuk menjadi kotak dengan bagian atas terbuka. Wadah diberi ventilasi pada bagian sisi sampingnya. Wadah penyimpanan dibuat dua jenis yaitu wadah terbuka yaitu wadah yang tidak diberi penutup, sedangkan wadah berpenutup yaitu wadah ditutup dengan penutup yang terbuat dari kawat yang ditutupi kain berwarna gelap. Penyimpanan dilakukan di ruang laboratorium.

\section{Pencucian dan sortasi ulang}

Pencucian dilakukan dengan menggunakan air. Umbi kentang yang sudah dicuci kemudian dikeringanginkan pada suhu ruang. Sortasi dilakukan kembali pada umbi kentang yang memiliki kecacatan fisik seperti kulit umbi yang terkelupas.

\section{Rancangan Penelitian}

Rancangan penelitian yang digunakan adalah rancangan acak lengkap (RAL) pola faktorial dengan dua faktor. Faktor pertama yaitu cara penyimpanan: disimpan pada wadah terbuka (K1) dan disimpan pada wadah berpenutup (K2). Faktor kedua adalah waktu penyimpanan: 2 minggu (T1), 4 minggu (T2), 6 minggu (T3), 8 minggu (T4), 10 minggu (T5). Penelitian menggunakan 10 perlakuan dengan 3 ulangan.

\section{Penghitungan Susut bobot (\%)}

Data bobot yang diperoleh selanjutnya dihitung persentase susut bobotnya berdasarkan rumus sebagai berikut :

Susut bobot $=\frac{\text { Bobotawal-bobotakhir }}{\text { Bobotawal }} \times 100 \%$

\section{Penghitungan Kadar Glukosa}

Penghitungan kadar glukosa dilakukan dengan menggunakan metode DNS, dengan urutan kerja sebagai berikut: Umbi kentang $0,05 \mathrm{~g}$ dilarutkan dalam alkohol $80 \% 5 \mathrm{ml}$, sehingga dihasilkan filtrat. $\mathrm{pH}$ filtrat diukur, jika asam ditambahkan $\mathrm{NaOH}$ sampai netral atau cukup basa. Filtrat dipanaskan pada penangas air $100^{\circ} \mathrm{C}$ selama 30 menit, lalu disaring. Sampel sebanyak $2 \mathrm{~mL}$ dimasukkan ke tabung reaksi, kemudian ditambahkan 2ml DNS. Sampel dipanaskan dalam penangas air mendidih selama 5 menit, kemudian didinginkan sampai mencapai suhu ruang. Absorbansi diukur pada panjang gelombang 540nm. Kadar glukosa didapat dengan menggunakan kurva glukosa standar.

\section{Penghitungan Kadar Karotenoid}

Penghitungan kadar karotenoid dilakukan dengan menggunakan metode spektrofotometri dengan urutan kerja sebagai berikut: Umbi kentang sebanyak $0,05 \mathrm{~g}$ dilarutkan dalam aseton $80 \% 5 \mathrm{~mL}$ sampai dihasilkan filtrat. Filtrat diletakkan dalam tabung cuvet dan diletakkan pada spektrofotometer. Absorbansi diukur pada panjang gelombang (480, $645,663) \mathrm{nm}$.

$\operatorname{Karotenoid}(\mu \mathrm{mol} / \mathrm{L})=$

[A480+(0,114xA663)]-0,638xA645xVx10 $\left.\left.0^{3}\right)\right]$

$112,5 \times \mathrm{W}$

A480: absorbansi panjang gelombang 480nm

A663: absorbansi panjang gelombang $663 \mathrm{~nm}$

A645: absorbansi panjang gelombang $645 \mathrm{~nm}$

$\mathrm{V}$ : volume ekstrak (ml)

$\mathrm{W}$ : berat sampel (g)

Konversi: $1 \mu \mathrm{mol} / \mathrm{l}=27,25 \mathrm{mg} / \mathrm{l}$

\section{Analisis data}

Data yang diperoleh kemudian dianalisis dengan ANOVA dilanjutkan dengan uji Dunca's Multiple Range Test (DMRT) pada taraf kepercayaan $95 \%$.

\section{HASIL DAN PEMBAHASAN}

\section{Susut Bobot}

Hasil analisis statistik menunjukkan bahwa cara penyimpanan dan waktu penyimpanan berpengaruh nyata terhadap penambahan susut bobot umbi kentang konsumsi $(\mathrm{p}<0,05)$. Berdasarkan uji lanjut Duncan terdapat perbedaan yang nyata terhadap rata-rata susut bobot umbi 
kentang konsumsiyang disajikan dalam Tabel 1 dan 2.

Tabel 1. Rata-rata susut bobot (\%) umbi kentang konsumsi pada perlakuan cara penyimpanan yang berbeda selama 70 hari

\begin{tabular}{cc}
\hline Perlakuan & Susut bobot $(\%)$ \\
\hline K1 & $4,24^{\mathrm{a}}$ \\
K2 & $3,00^{\mathrm{b}}$ \\
\hline
\end{tabular}

Keterangan: Angka-angka yang diikuti huruf superskrip yang berbeda dalam satu kolom menunjukkan perbedaan yang nyata berdasarkan uji Duncan pada taraf kepercayaan $95 \%$.

Tabel 2. Rata-rata susut bobot (\%) umbi kentang konsumsi pada perlakuan waktu penyimpanan yang berbeda

\begin{tabular}{cc}
\hline Perlakuan & Susut bobot (\%) \\
\hline T1 & $1,80^{\mathrm{c}}$ \\
T2 & $2,65^{\mathrm{bc}}$ \\
T3 & $3,41^{\mathrm{b}}$ \\
T4 & $4,75^{\mathrm{a}}$ \\
T5 & $5,50^{\mathrm{a}}$ \\
\hline
\end{tabular}

Keterangan: Angka-angka yang diikuti huruf superskrip yang berbeda dalam satu kolom menunjukkan perbedaan yang nyata berdasarkan uji Duncan pada taraf kepercayaan $95 \%$.

Selisih persentase susut bobot antara cara penyimpanan di wadah terbuka (K1) dan wadah berpenutup (K2) yaitu sebesar 29,24\%, hal ini menunjukkan bahwa penyimpanan umbi kentang selama 70 hari pada cara penyimpanan di wadah terbuka (K1) memiliki susut bobot lebih tinggi $29,24 \%$ daripada cara penyimpanan di wadah berpenutup (K2). Susut bobot selama pasca panen sangat penting karena saat terjadi susut bobot 5\% sudah mengakibatkan perubahan mutu fisiologis umbi, sehingga penyusutan tersebut mengakibatkan pembentukan keriput pada bagian luar kulit umbi. Cara penyimpanan pada wadah berpenutup (K2) bisa dijadikan sebagai rekomendasi penyimpanan umbi kentang khususnya untuk penyimpanan jangka panjang.
Umbi kentang memiliki rata-rata selisih susut bobot sebesar $28,41 \%$ per 2 minggu selama 70 hari penyimpanan. Peningkatan susut bobot yang cukup besar dapat mempengaruhi kualitas umbi kentang. Lamanya penyimpanan menyebabkan kenaikan susut bobot umbi kentang, hal ini sesuai dengan pernyataan Asgar dan Asandhi (1992) yang menyatakan bahwa semakin lama umbi kentang disimpan semakin besar susutnya.

Susut bobot umbi kentang akan mengalami penambahan seiring dengan lamanya waktu penyimpanan. Semakin lama disimpan menyebabkan kandungan air di dalam umbi kentang akan berkurang, hal ini sesuai dengan pernyataan Jufri (2011) bahwa umbi kentang terdiri dari $80 \%$ air, kehilangan bobot dapat disebabkan oleh kehilangan air. Air dalam umbi lebih mudah hilang di suhu ruang daripada di suhu kamar melalui proses evaporasi. Beukema dan Zaag (2007) menambahkan bahwa evaporasi umbi kentang akan lebih besar terjadi pada suhu kamar daripada suhu dingin.

Besarnya angka susut bobot diikuti dengan adanya pertumbuhan tunas yang tidak lain berasal dari perombakan parenkim penimbun. Wiersema (1989) menambahkan bahwa kehilangan air dari umbi kentang akan menjadi lebih besar apabila umbi telah bertunas. Kondisi lingkungan tempat penyimpanan juga mempengaruhi besarnya angka susut bobot, hal ini didukung oleh pernyataan dari Jufri (2011) bahwa kelembaban yang terlalu rendah akan menyebabkan besarnya kehilangan bobot pada umbi kentang.

\section{Kadar Glukosa}

Hasil analisis statistik menunjukkan bahwa waktu penyimpanan berpengaruh nyata terhadap kadar glukosa umbi kentang konsumsi $(\mathrm{p}<0,05)$, sedangkan cara penyimpanan tidak berpengaruh terhadap kadar glukosa umbi kentang konsumsi ( $p>0,05)$. Berdasarkan uji lanjut Duncan, waktu penyimpanan berbeda nyata terhadap rata-rata kadar glukosa umbi kentang konsumsi yang disajikan dalam Tabel 3.

Rata-rata kadar glukosa kentang tertinggi yaitu pada perlakuan waktu penyimpanan selama 2 minggu $(44,03 \mathrm{mg} / \mathrm{l})$ dan kentang yang disimpan 
selama 8 minggu mempunyai kadar glukosa yang terendah $(38,75 \mathrm{mg} / \mathrm{l})$. Selama penyimpanan proses metabolisme terus berjalan, sementara laju respirasi dapat ditekan sehingga terjadi akumulasi gula reduksi (Kusdibyo, 2004). Tanaman seringkali menyimpan karbohidrat dalam buahnya untuk persediaan energi. Karbohidrat tersebut kemudian digunakan oleh buah untuk melangsungkan keaktifan dan sisa hidupnya (Santoso, 2013).

Tabel 3.Rata-rata kadar glukosa (mg/l) umbi kentang konsumsi pada perlakuan waktu penyimpanan yang berbeda

\begin{tabular}{cc}
\hline Perlakuan & $\begin{array}{c}\text { Kadar glukosa } \\
(\mathrm{mg} / \mathrm{l})\end{array}$ \\
\hline T1 & $44,03^{\mathrm{a}}$ \\
T2 & $41,41^{\mathrm{b}}$ \\
T3 & $41,34^{\mathrm{b}}$ \\
T4 & $38,75^{\mathrm{c}}$ \\
\hline
\end{tabular}

Keterangan: Angka-angka yang diikuti huruf superskrip yang berbeda dalam satu kolom menunjukkan perbedaan yang nyata berdasarkan uji Duncan pada taraf kepercayaan $95 \%$.

Rata-rata kadar glukosa kentang tertinggi yaitu pada perlakuan waktu penyimpanan selama 2 minggu $(44,03 \mathrm{mg} / \mathrm{l})$ dan kentang yang disimpan selama 8 minggu mempunyai kadar glukosa yang terendah $(38,75 \mathrm{mg} / \mathrm{l})$. Selama penyimpanan proses metabolisme terus berjalan, sementara laju respirasi dapat ditekan sehingga terjadi akumulasi gula reduksi (Kusdibyo, 2004). Tanaman seringkali menyimpan karbohidrat dalam buahnya untuk persediaan energi. Karbohidrat tersebut kemudian digunakan oleh buah untuk melangsungkan keaktifan dan sisa hidupnya (Santoso, 2013).

Penggunaan gula sebagai energi pada proses metabolisme disesuaikan dengan kondisi lingkungan di sekitar produk, selain itu juga tergantung adanya kebutuhan energi untuk menyuplai pertumbuhan vegetatif (tunas), sehingga bisa dikatakan perombakan pati menjadi gula akan semakin besar ketika tunas mulai tumbuh. Lama penyimpanan mengakibatkan penurunan kadar glukosa pada umbi kentang. Penurunan mutu tersebut dikarenakan kentang memiliki kandungan air sekitar $80 \%$ sehingga menyebabkan mudah rusak. Produk yang mudah rusak akan lebih mudah diserang oleh mikroba, hal ini sesuai dengan pernyataan dari Zulkarnaen (2009) yang menyatakan bahwa buah dan sayur merupakan jenis pangan yang mudah rusak dikarenakan kandungan airnya yang cukup tinggi sehingga memungkinkan mikroba dan bakteri lain tumbuh didalamnya dan hal ini bisa menurunkan mutu pangan.

Lamanya penyimpanan dapat merangsang adanya pertumbuhan tunas pada umbi kentang. Keberadaan tunas juga mempengaruhi kadar glukosa umbi kentang selama penyimpanan. Ketika tunas sudah mulai tumbuh maka akan terjadi penurunan kadar glukosa di dalam umbi. Karbohidrat dipecah menjadi glukosa dan ditranslokasikan dari umbi ke tunas, hal ini dikarenakan tunas membutuhkan pasokan suplai energi selama pertumbuhannya. Asgar (1998) menyatakan bahwa energi yang berasal dari timbunan karbohidrat yang berubah menjadi gula sederhana digunakan untuk pertunasan bila penyimpanan lama.

\section{Kadar Karotenoid}

Hasil analisis statistik menunjukkan bahwa interaksi antara cara dan waktu penyimpanan tidak berpengaruh nyata terhadap kadar karotenoid umbi kentang konsumsi $(p<0,05)$ dan berdasarkan uji lanjut Duncan tidak terdapat perbedaan nyata yang disajikan dalam Tabel 4 berikut.

Tabel 4. Rata-rata kadar karotenoid (mg/l) umbi kentang konsumsi pada perlakuan cara penyimpanan dan waktu penyimpanan yang berbeda

\begin{tabular}{ccc}
\hline \multirow{2}{*}{ Perlakuan } & \multicolumn{2}{c}{ kadar karotenoid $(\mathrm{mg} / \mathrm{l})$} \\
\cline { 2 - 3 } & K1 & K2 \\
\hline T1 & 121,79 & 149,04 \\
T2 & 137,46 & 167,84 \\
T3 & 127,52 & 110,81 \\
T4 & 77,04 & 99,55 \\
T5 & 98,36 & 94,45 \\
\hline
\end{tabular}

Cara penyimpanan di wadah tertutup (K2) dapat mengurangi kerusakan karotenoid umbi kentang karena dapat menghindarkan adanya 
kehadiran oksigen yang lebih banyak. Hal ini ditunjukkan oleh umbi kentang yang disimpan dengan perlakuan disimpan pada wadah berpenutup (K2) selama 70 hari memiliki rata-rata kadar karotenoid yang lebih tinggi yaitu sebesar 124,338 $\mathrm{mg} / \mathrm{L}$. Berbeda dengan perlakuan penyimpanan pada wadah terbuka (K1) yang memiliki rata-rata kadar karotenoid lebih kecil yaitu sebesar 112,434 $\mathrm{mg} / \mathrm{l}$, hal ini dikarenakan pada penyimpanan di wadah terbuka akan lebih banyak terdapat oksigen atau udara. Setyabudi (1994) dalam Ruwanti (2010) menyatakan bahwa di udara bebas karoten mengikat oksigen dan menaikkan kecepatan pembentukan warna yang lebih pucat. Autooksidasi beta karoten murni dimulai setelah beberapa hari kontak dengan udara. Legowo (2005) menambahkan adanya udara atau oksigen dapat mempengaruhi kestabilan karoten.

Oksigen $\left(\mathrm{O}_{2}\right)$ merupakan senyawa yang berperan dalam pembakaran glukosa saat terjadi respirasi. Lama penyimpanan menyebabkan umbi kentang lebih lama berinteraksi dengan adanya $\mathrm{O}_{2}$, sehingga proses perombakan di dalam umbi juga akan semakin besar. Perombakan yang terjadi mempengaruhi kadar karotenoid. Perlakuan waktu penyimpanan menyebabkan penurunan kadar glukosa pada umbi kentang. Kadar glukosa sangat mempengaruhi kadar karotenoid, hal ini dikarenakan glukosa merupakan salah satu sumber energi di dalam menyumbang senyawa Asetil ko-A pada proses pembentukan karotenoid. Asetil ko-A merupakan senyawa penting di dalam biosintesis karotenoid (Robinson, 1995). Asetil ko-A didapatkan tidak lain berasal dari proses metabolisme melalui perombakan glukosa.

Oksigen $\left(\mathrm{O}_{2}\right)$ juga berperan dalam proses oksidasi selama penyimpanan. Peristiwa oksidasi merupakan salah satu faktor yang mempengaruhi kehilangan karotenoid pada sayuran. Macdougall (2003) menjelaskan alasan utama kehilangan karotenoid pada sayuran adalah karena oksidasi struktur tidak jenuh karotenoid. Oksidasi yang muncul antara lain autooksidasi, reaksi ini muncul secara spontan karena keberadaan oksigen. Erawati (2006) menambahkan banyaknya ikatan rangkap pada struktur kimia beta karoten menyebabkan bahan ini menjadi sangat sensitif terhadap reaksi oksidasi ketika terkena udara
$\left(\mathrm{O}_{2}\right)$. Berdasarkan pada hal tersebut cara penyimpanan yang berbeda hanya memberikan pengaruh kecil terhadap perubahan kadar karotenoid, hal ini dikarenakan keberadaan $\mathrm{O}_{2}$ selalu ada selama penyimpanan dimana konsentrasinya tidak boleh terlau besar maupun terlalu kecil.

\section{KESIMPULAN}

1. Cara penyimpanan di wadah terbuka (K1) cenderung meningkatkan susut bobot daripada wadah tertutup (K2), sedangkan waktu penyimpanan cenderung menurunkan kadar glukosa dan kadar karotenoid umbi kentang konsumsi.

2. Interaksi antara cara dan waktu penyimpanan tidak berpengaruh nyata terhadap susut bobot, kadar glukosa dan kadar karotenoid $(\mathrm{p}>0,05)$

3. Penyimpanan umbi kentang konsumsi sebaiknya dijauhkan dari adanya kehadiran cahaya dengan masa simpan kurang dari 4 minggu

\section{DAFTAR PUSTAKA}

Asgar A. and Asandhi. A.A. 1992. Improvement of Ware Potato Store Method. Bul. Penel. Hort. XX (4) : 138-142.

Asgar A. dan Marpaung, L. 1998. Pengaruh Umur Panen dan Lama Penyimpanan terhadap Kualitas Kentang Goreng. Balai Penelitian Tanaman Sayuran. J.Hort.8(3) : 1208-1216.

Astawan, M. 2004. Sehat Bersama Aneka Serat Pangan Alami. Cetakan I. Penerbit Tiga Serangkai, Solo.

Beukema, H.P and van der Zaag, D. E. 2007. Introduction to Potato Production. Edisi 3. Pudoc Wageningen. Netherland.179 p.

Campbell, N. A., Reece, J. B. and Mitchell, L. E. 1990. Biology 2 nd edition. The BenjaminCummings Publishing Company. California. $1165 \mathrm{pp}$.

Erawati, C. M., Tien, R. M., dan Purwiyatno H. 2006. Kendali Stabilitas Beta Karoten Setama Proses Produksi Tepung Ubi Jalar. 
Forum Pascasarjana Vol. 29 No.4 Oktober 2006: 289-299.

Jufri, A. F. 2011. Penanganan Penyimpanan Kentang Bibit (Solanum tuberosum L.) di Hikmah Farm Pangalengan, Bandung, Jawa Barat. Skripsi. Fakultas Pertanian Institut Pertanian Bogor.

Kusdibyo dan Asandhi, A.A. 2004. Waktu Panen Dan Penyimpanan Pasca Panen Untuk Mempertahankan Mutu Umbi Kentang Olahan. Ilmu Pertanian Vol. 11 No.1, 2004 : $51-62$.

Legowo, A. 2005. Pengaruh Blanching terhadap Sifat Sensoris dan Kadar Provitamin Tepung Labu Kuning. Yogyakarta. Fakultas Teknologi Pertanian Universitas Gadjah Mada.

Lidya. 2010. Foods That Boost Your Immune (Online) (www.ligagame.com/forum/index.ph p?action=printpage;topic $=47656.0) . \quad$ Diakses pada 4 Juni 2012)

Macdougal, D. B. 2003. Colour in Food. Woodhead Publising United. Boston, USA.

Morris, W. L., Ducreux, L., Grifths, D. W., Stewart, D., Davies, H. V., and Taylor, M. A. 2004. Carotenogenesis During Tuber Development And Storage In Potato. Journal of Experimental Botany 399 (55): 975-982.

Pandey, S., Singh, J., Upadhyay, A. K., Ram, D., and Rai, M. 2003. Ascorbate and Carotenoid Content in an Indian Collection of Pumkin (Cucurbita moschata Duch.Ex Poir.). Cucurbit Genetics Cooperative Report 26: 51-53.

Rismawati, L. dan Megayani S. R. 2009. Penanganan Pasca Panen Kentang (Solanum Tuberosum L.) Di Hikmah Farm, Pangalengan, Bandung, Jawa Barat. Makalah Seminar Departemen Agronomi dan Hortikultura Fakultas Pertanian Institut Pertanian Bogor.

Robinson, T. 1995 (Diterjemahkan oleh K. Padmawirata). Kandungan Organik Tumbuhan Tinggi. ITB. Bandung.
Ruwanti S. 2010. Optimasi Kadar $\beta$-Karoten Pada Proses Pembuatan Tepung Ubi Jalar Oranye (Ipomoea Batatas L) Dengan Menggunakan Response Surface Methodology (RSM). Surakarta. Fakultas Pertanian Universitas Sebelas Maret.

Santoso, B. 2013. Bahan Ajar Pasca panen Hortikultura.http://fp.unram.ac.id/.diakses pada 20 Desember 2013.

The International Potato Center. 2008. Facts and Figures: 2008-The International Year ofthe Potato.CIP. http://www.potato2008.org [5Oktober 2010].

Wardkan, 2010. Petunjuk Praktikum Fisiologi Dan Teknologi Pasca Panen. Fakultas Pertanian. Universitas Mataram.

Wiersema, S. G. 1989. Storage requirements for Potato Tubers. Postharvest Technology Thrust. International Potato Center (CIP, Bangkok, Thailand) 9p.

Zulkarnaen. 2009. Dasar-dasar Holtikultura. Bumi Aksara. Jakarta. 